\title{
PARTISIPASI MAHASISWA DALAM KULIAH KERJA NYATA DI PT SANG HYANG SERI SIDENRENG RAPPANG
}

\author{
HASLINDA \\ Ilmu Pemerintahan, Fisip,Universitas Muhammadiyah Sidenreng Rappang \\ E-mail : haslindahasan010@gmail.com
}

\begin{abstract}
Abstrak
PT Sang Hyang Seri (Persero) merupakan Badan Usaha Milik Negara (BUMN) yang bergerak dalam bidang perbenihan pertanian dituntut untuk menyiapkan benih secara tepat untuk memenuhi kebutuhan konsumen (petani) dan laba yang optimal untuk kelangsungan hidup perusahaan. Oleh karena itu, produktivitas pabrik benih dalam memproduksi benih merupakan salah satu komponen penting dalam menunjang kesinambungan usaha. Metode yang dilakukan dalam pengabdian yaitu dengan metode partisipasi. Keikutsertaan atau keterlibatan mahasiswa Kuliah Kerja Nyata dalam kegiatan pengemasan benih yang dilaksanakan mulai pada tanggal 20 Januari 2022. Peserta partisipasi dalam kegiatan pengemasan benih yaitu karyawan PT SHS, mahasiswa KKN dan mahasiswa KKN dari kampus lain (Universitas Muhammadiyah ParePare). Adapun pemberian materi dari karyawan PT SHS mulai dari pengenalan perusahaan hingga pengemasan benih. Sebelum Mahasiswa Kuliah Kerja Nyata Tematik ikut serta dalam pengemasan produk dari PT Sang Yhang Seri sudah dibekali dengan Observasi atau pengenalan perusahaan dengan pemateri yang sudah ditunjuk oleh Kepala Unit PT SHS cabang Sidenreng Rappang. Partisipasi mahasiswa KKN Tematik di PT Sang Hyang Seri ( PT SHS) terlibat langsung dalam produksi benih dan cepat beradaptasi dengan karyawan PT SHS. Saran daripada kegiatan pengabdian ini yaitu diharapkan mahasiswa kuliah kerja nyata KKN Tematik kedepan lebih baik lagi dalam berpartisipasi dan menyusun secara maksimal untuk kegiatan penunjang KKN yang berkaitan dengan PT SHS dan diharapkan mempelancar produksi.
\end{abstract}




\section{PENDAHULUAN}

Berdasarkan Undang-Undang Republik Indonesia Nomor 12Tahun 2012 tentang Pendidikan Tinggi pasal 1 ayat 9 menyatakan bahwa Tridharma adalah kewajiban Perguruan Tinggi untuk menyelenggarakan Pendidikan, Penelitian dan Pengabdian Kepada Masyarakat. Kemudian dijelaskan pula pada ayat 11 bahwa pengabdian kepada masyarakat adalah kegiatan sivitas akademika yang memanfaatkan Ilmu Pengetahuan dan Teknologi untuk memajukan kesejahteraan masyarakat yang mencerdaskan kehidupan bangsa. Pada Perguruan Tinggi pelaksanaan pengabdian kepada masyarakat yang dapat dilakukan melalui Kuliah Kerja Nyata (KKN). Salah satu Kuliah Kerja Nyata yang dilaksanakan saat ini oleh masing-masing institusi yaitu Kuliah Kerja Nyata Tematik (KKNT). (Muniarty \& Saputri, 2021)

PT Sang Hyang Seri (Persero) merupakan Badan Usaha Milik Negara (BUMN) yang bergerak dalam bidang perbenihan pertanian dituntut untuk menyiapkan benih secara tepat untuk memenuhi kebutuhan konsumen (petani) dan laba yang optimal untuk kelangsungan hidup perusahaan. Oleh karena itu, produktivitas pabrik benih dalam memproduksi benih merupakan salah satu komponen penting dalam menunjang kesinambungan usaha.

Menurut Simatupang (dalam Yuwono, 2001:124) memberikan beberapa rincian tentang partisipasi, sebagai berikut:

a. Partisipasi berarti apa yang kita jalankan adalah bagian dari usaha bersama yang dijalankan bahumembahu dengan saudara kita sebangsa dan setanah air untuk membangun masa depan bersama.

b. Partisipasi berarti pula sebagai kerja untuk mencapai tujuan bersama diantara semua warga negara yang mempunyai latar belakang kepercayaan yang beraneka ragam dalam negara pancasila kita, atau dasar hak dan kewajiban yang sama untuk memberikan sumbangan demi terbinanya masa depan yang baru dari bangsa kita.

c. Partisipasi tidak hanya berarti mengambil bagian dalam pelaksanaan-pelaksanaan, perencanaan pembangunan. Partisipasi berarti memberikan sumbangan agar dalam pengertian kita mengenai pembangunan kita nilai-nilai kemanusiaan dan cita- cita mengenai keadilan sosial tetap dijunjung tinggi.

d. Partisipasi dalam pembangunan berarti mendorong ke arah pembangunan yang serasi dengan martabat manusia. Keadilan sosial dan keadilan Nasional dan yang memelihara alam sebagai lingkungan hidup manusia juga untuk generasi yang akan datang. Dengan adanya partisipasi mahasiswa diharapkan dapat mewujudkan program KKN Tematik ini. (Latif, Rusdi, et al., 2019)

Partisipasi dapat terjadi pada 4 (empat) jenjang, yaitu: 
a. Partisipasi dalam proses pembuatan keputusan. Setiap proses penyelenggaraan, terutama dalam kehidupan bersama masyarakat, pasti melewati tahap penentuan kebijaksanaan. Partisipasi masyarakat pada tahap ini sangat mendasar sekali, terutama karena yang di ambil menyangkut nasib mereka secara keseluruhan yang menyangkut kepentingan bersama. Partisipasi dalam hal pengambilan keputusan ini bermacam-macam, seperti kehadiran rapat, diskusi, sumbangan pemikiran, tanggapan atau penolakan terhadap program yang ditawarkan.

b. Partisipasi dalam pelaksanaan. Partisipasi masyarakat dalam pelaksanaan program merupakan lanjutan dari rencana yang telah disepakati sebelumnya. Dalam hal ini ditegaskan bahwa partisipasi dalam pembangunan ini dapat dilakukan melalui keikutsertaan masyarakat dalam memberikan konstribusi guna menunjang pelaksanaan pembangunan

c. Partisipasi dalam pengambilan manfaat. Partisipasi ini tidak terlepas terlepas dari kualitas maupun kuantitas dari hasil pelaksanaan program yang bisa dicapai. Dari segi kualitas, keberhasilan suatu program akan ditandai dengan adanya peningkatan output, sedangkan dari segi kuantitas dapat dilihat seberapa besar persentase keberhasilan program yang dilaksananakan, apakah sesuai dengan target yang telah ditetapkan.

d. Partisipasi dalam menikmati hasil dapat dilihat dari tiga segi, yaitu dari aspek manfaat materialnya, materialnya, manfaat sosialnya dan manfaat pribadi. Partisipasi dalam evaluasi ini berkaitan dengan masalah pelaksanaan program secara menyeluruh. Partisipasi ini bertujuan untuk mengetahui apakah pelaksanaan program telah sesuai dengan yang ditetapkan atau ada penyimpangan. (Latif, Rusdi, et al., 2019)

Partisipasi dimaknai yaitu "partisipasi adalah keikutsertaan untuk mengakomodasikan kepentingan dalam proses penyusunan rencana pembangunan" Dari pengertian di atas dapat disimpulkan bahwa partisipasi merupakan keterlibatan atau keikutsertaan seseorang masyarakat dalam proses interaksi sosial, pengidentifikasian masalah dan potensi yang ada di dalam situasi tertentu, baik dalam pengambilan keputusan (solusi) menangani masalah, pelaksanaan upaya mengatasi masalah, dan proses keterlibatan masyarakat di dalam mengevaluasi perubahan yang terjadi. (Mustanir \& Abadi, 2017)

Partisipasi dimaknai yaitu "partisipasi masyarakat adalah keikutsertaan

masyarakat untuk mengakomodasikan kepentingan mereka dalam proses penyusunan rencana pembangunan" Dari pengertian di atas dapat disimpulkan bahwa partisipasi masyarakat merupakan keterlibatan atau keikutsertaan seseorang masyarakat dalam proses interaksi sosial, 
pengidentifikasian masalah dan potensi yang ada di masyarakat dalam situasi tertentu, baik dalam pengambilan keputusan (solusi) menangani masalah.(Mustanir \& Abadi, 2017)

Partisipasi diberi makna sebagai keterlibatan masyarakat dalam proses politik yang seluas-luasnya baik dalam proses pengambilan keputusan dan monitoring kebijakan yang dapat mempengaruhi kehidupan mereka. Berbagai peraturan yang memberikan ruang bagi partisipasi masyarakat secara substantif belum mengatur bagaimana partisipasi masyarakat itu dilaksanakan. (Sapri et al., 2019)

Pengertian partisipasi masyarakat disini merupakan keikutsertaan dalam melakukan kegiatan pengidentifikasian problem dan potensi-potensi yang ada didalam masyarakatnya.(Latif, Mustanir, et al., 2019)

Indikator Partisipasi Masyarakat :

a) Terlibat memikul tanggung jawab pelaksanaan pembangunan b) Musyawarah perencanaan pembangunan c) Pelaksana hasil perencanaan pembangunan (Mustanir \& Darmiah, 2016)

partisipasi dengan bertolak pada urutan proses perencanaan pembangunan, maka secara rinci jenis partisipasi masyarakat dalam pembangunan sebagai berikut:

1) Partisipasi dalam pengambilan keputusan,

2) Partisipasi dalam pelaksanaan kegiatan,

3) Partisipasi dalam pemantauan dan evaluasi pembangunan,
4) Partisipasi dalam pemanfaatan hasil-hasil pembangunan. (Mustanir \& Razak, 2017)

Partisipasi masyarakat dalam pembangunan sangat tergantung pada peranan pemerintah dalam memberikan dan menimbulkan stimulasi dan motivasi yang mengarah pada kreativitas masyarakat. (Irwan et al., 2019). Dalam upaya pembangunan diperlukan bentuk partisipasi masyarakat setempat yang di mulai dari proses perencanaannya sampai pada proses pelaksanaannya.(Irwan et al., 2021)

Partisipasi masyarakat di dalam setiap proses pembuatan kebijakan publik merupakan hal penting sebagai cermin asas demokrasi di suatu negara.(Ahmad Mustanir et al., 2019)

\section{METODE}

Metode yang dilakukan dalam pengabdian yaitu dengan metode partisipasi. Keikutsertaan atau keterlibatan mahasiswa Kuliah Kerja Nyata dalam kegiatan pengemasan benih yang dilaksanakan mulai pada tanggal 20 Januari 2022. Peserta partisipasi dalam kegiatan pengemasan benih yaitu karyawan PT SHS, mahasiswa KKN dan mahasiswa KKN dari kampus lain (Universitas Muhammadiyah Pare-Pare). Adapun pemberian materi dari karyawan PT SHS mulai dari pengenalan perusahaan hingga pengemasan benih.

\section{HASIL DAN PEMBAHASAN}


Sebelum Mahasiswa Kuliah Kerja Nyata Tematik ikut serta dalam pengemasan produk dari PT Sang Yhang Seri sudah dibekali dengan Observasi atau pengenalan perusahaan dengan pemateri yang sudah ditunjuk oleh Kepala Unit PT SHS cabang Sidenreng Rappang. Observasi dilakukan merupakan bagian penting dari KKN Tematik, hingga mahasiswa dapat mengenal isi dan sejarah PT SANG YHANG SERI. Materi yang disampaikan oleh masingmasing pemateri dikemas sesimpel mungkin dan mudah dimengerti serta diimplementasikan oleh peserta KKN selama berada dilokasi. Setiap akhir materi mahasiswa diberikan kesempatan untuk bertnya dan mendiskusikan hal-hal yamg kemungkinan akan menjadi kendala dalam melaksanakan program kerja dilapangan.

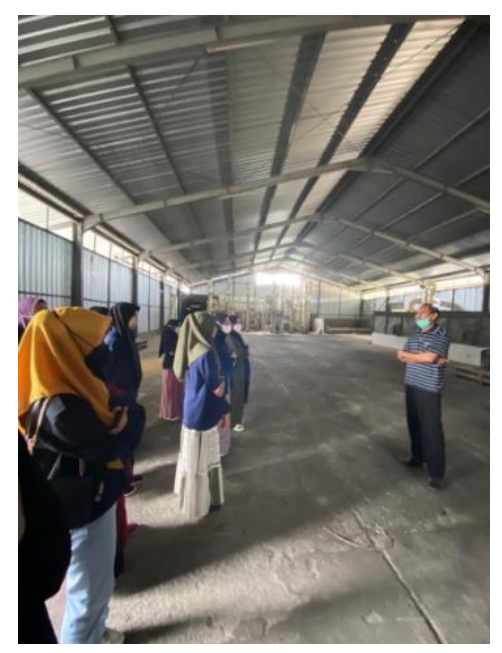

Gambar 1 Pemateri Pengenalan PT SHS Sidenreng Rappang

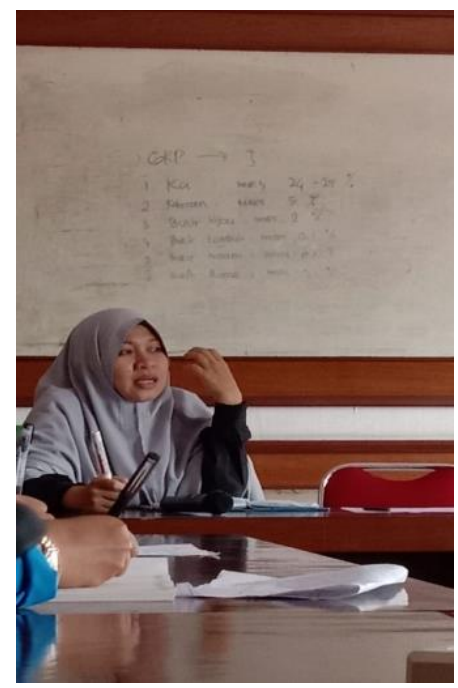

Gambar 2 Materi Tentang

\section{Sertifikasi Benih}

Dalam kegiatan ini pendekatan yang digunakan mahasiswa KKN Tematik yaitu dengan metode pendekatan secara partisipatif langsung. Pendekatan ini memiliki peluang untuk mengembangkan dan menjamin suatu komunitas sosial yang memungkinkan terjadinya proses belajar untuk beradaptasi dan berintegritasi dengan lingkungannya. Melalui metode ini sangat efektif dilakukan dengan begitu jika ada setiap kegiatan di PT SHS SIDRAP mahasiswa kuliah kerja nyata dengan terbuka tanpa diperintah bisa berkolaborasi langsung dengan kegiatan yang ada. 


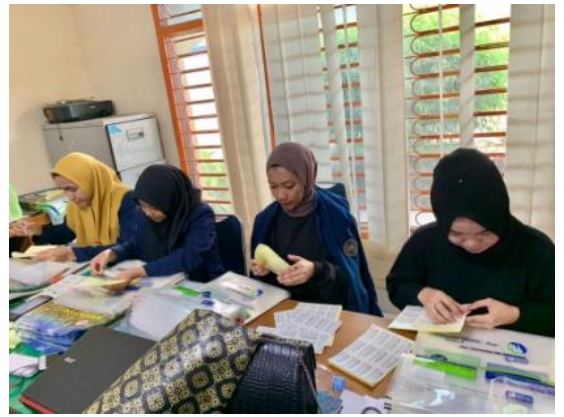

Gambar 3 Pemasangan Label pada Kemasan Benih

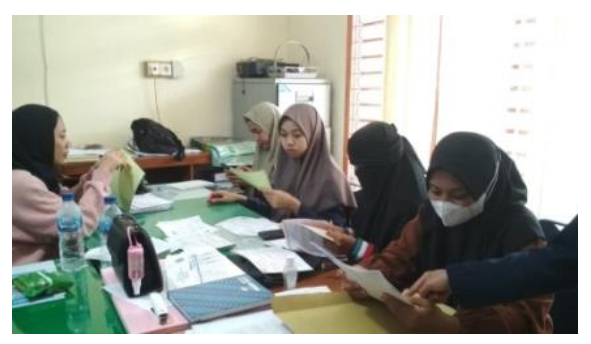

Gambar 4

Partisipasi

1. Pemikiran / ide adalah yang menyebabkan pikiran mendapatkan pengertian baru dengan perantara hal yang sudah diketahui. Yang beraksi dalam pemikiran, bukan hanya pikiran atau akal budi saja tetapi sesungguhnya manusia secara keseluruhan.

2. Uang / dana adalah sesuatu yang tersedia dan secara umum diterima sebagai alat pembayaran bagi pembelian barang-barang dan jasajasa serta kekayaan berharga lainnya bahkan untuk pembayaran hutang.

3. Materi / barang adalah benda-benda yang berwujud, yang digunakan masyarakat untuk memenuhi kebutuhannya atau untuk menghasilkan benda lain yang akan memenuhi kebutuhan masyarakat.(Mustanir et al., 2018)

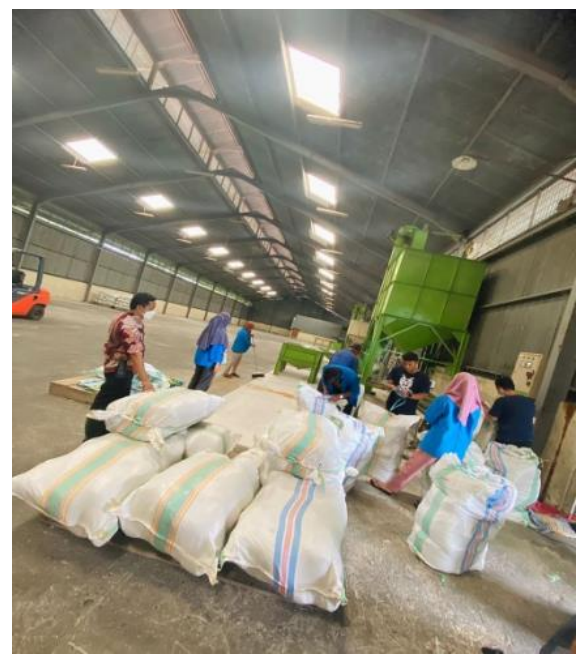

Gambar 5 Pengemasan Benih

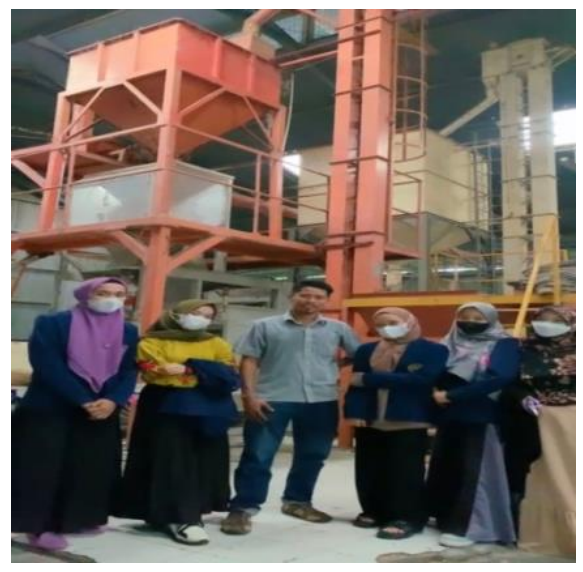

Gambar 6

\section{KESIMPULAN DAN SARAN}

Partisipasi mahasiswa KKN Tematik di PT Sang Hyang Seri (PT SHS) terlibat langsung dalam produksi benih dan cepat beradaptasi dengan karyawan PT SHS. Saran daripada kegiatan pengabdian ini yaitu diharapkan mahasiswa kuliah kerja nyata KKN Tematik kedepan lebih baik lagi dalam berpartisipasi dan menyusun secara 
maksimal untuk kegiatan penunjang KKN yang berkaitan dengan PT SHS dan diharapkan mempelancar produksi.

\section{DAFTAR PUSTAKA}

Ahmad Mustanir, M., Andi Uceng, M.Nurzin R. Kasau, B., \& Andriani, D. (2019). KARAKTERISTIK KEPEMIMPINAN LURAH TERHADAP PARTISIPASI

MASYARAKAT DALAM MUSYAWARAH PERENCANAAN PEMBANGUNAN DI KELURAHAN DUAMPANUA KECAMATAN BARANTI KABUPATEN SIDENRENG RAPPANG. 2(2), 145-172.

Irwan, Latif, A., \& Mustanir, A. (2021). PENDEKATAN PARTISIPATIF DALAM PERENCANAAN PEMBANGUNAN DI KABUPATEN SIDENRENG RAPPANG. Jurnal Kajian, Penelitian Dan Pengembangan Pendidikan, 9(2), 137-151.

Irwan, Latif, A., Sofyan, Mustanir, A., \& Fatimah. (2019). Gaya Kepemimpinan, Kinerja Aparatur Sipil Negara dan Partisipasi Masyarakat Terhadap Pembangunan di Kecamatan Kulo Kabupaten Sidenreng Rappang. Jurnal Moderat, 5(1), 32-43.

https://jurnal.unigal.ac.id/index.php/mo derat

Latif, A., Mustanir, A., \& Irwan, I. (2019). Pengaruh Kepemimpinan Terhadap Partisipasi Masyarakat Pada Perencanaan Pembangunan. JAKPP (Jurnal Analisis Kebijakan \& Pelayanan Publik), 5(2), 144-164. https://doi.org/10.31947/jakpp.v1i2.797 7

Latif, A., Rusdi, M., Mustanir, A., \& Sutrisno, M. (2019). Partisipasi Masyarakat Dalam Pembangunan Infrastruktur Di Desa Timoreng Panua Kecamatan Panca Rijang Kabupaten Sidenreng Rappang Dosen Ilmu Pemerintahan Stisip Muhammadiyah Rappang Dosen Ilmu Administrasi Negara Stisip Muhammadiyah Rappang 5). Jurnal MODERAT, 5(1), 1-15. https://jurnal.unigal.ac.id/index.php/mo derat/article/view/1898

Muniarty, P., \& Saputri, D. (2021). PENINGKATAN KOMPETENSI MAHASISWA MELALUI PEMBEKALAN KULIAH KERJA NYATA TEMATIK. 2(1), 1-12.

Mustanir, A., \& Abadi, P. (2017). Partisipasi Masyarakat Dalam Musyawarah Rencana Pembangunan Di Kelurahan Kanyuara Kecamatan Watang Sidenreng Kabupaten Sidenreng Rappang. Jurnal Politik Profetik, 5(2), 247-261. http://journal.uinalauddin.ac.id/index.php/jpp/article/vie wFile/4347/3986\%0Ahttp://journal.uinalauddin.ac.id/index.php/jpp/issue/view 1636

Mustanir, A., \& Darmiah, D. (2016). Implementasi Kebijakan Dana Desa Dan Partisipasi Masyarakat Dalam Pembangunan Di Desa Teteaji Kecamatan Tellu Limpoe Kabupaten Sidenreng Rappang. Jurnal Politik Profetik, 4(2), 225-238. http://journal.uinalauddin.ac.id/index.php/jpp/article/vie w/2749\%0Ahttp://journal.uinalauddin.ac.id/index.php/jpp/issue/view 1457

Mustanir, A., Dema, H., Syarifuddin, H., 
Irwan, \& Sri Wulandari, K. M. (2018).

Pengaruh Motivasi dan Partisipasi

Masyarakat terhadap Pembangunan di

Kelurahan Lalebata Kecamatan Panca

Rijang Kabupaten Sidenreng Rappang.

Jurnal Ilmiah Clean Government

(JCG), 2(1), 27-39.

http://lonsuit.unismuhluwuk.ac.id/index

.php/clean/article/view/212

Mustanir, A., \& Razak, M. R. R. (2017).

Nilai Sosial Budaya Pada Partisipasi

Masyarakat Etnik Towani Tolotang

Dalam Musyawarah Rencana

Pembangunan. Prosiding Konferensi

Nasional Ke-6 Asosiasi Program

Pascasarjana Perguruan Tinggi

Muhammadiyah Aisyiyah (APPPTMA), September, 1-7.

http://asosiasipascaptm.or.id/index.php/ publikasi/prosiding-konferensi-

nasional-appptma-ke-6

Sapri, Mustanir, A., Ibrahim, M., Astinah

Adnan, A., \& Wirfandi. (2019).

Peranan Camat dan Partisipasi

Masyarakat Dalam Musyawarah

Perencanaan Pembangunan Di

Kecamatan Enrekang Kabupaten

Enrekang. MODERAT: Jurnal Ilmiah

Ilmu Pemerintahan, 5(2), 33-48.

https://jurnal.unigal.ac.id/index.php/mo

derat/article/view/2127 